\title{
Prototype Portal Students and Lecturers of UPT PSI Muria Kudus University using Web-based
}

\author{
Tri Listyorini ${ }^{1}$, Rizkysari Meimaharani ${ }^{2}$ \\ \{trilistyorini@umk.ac.id ${ }^{1}$,rizky.sari@umk.ac.id²\} \\ Universitas Muria Kudus, Gondang Manis POBOX 53 Bae Kudus, Indonesia ${ }^{12}$
}

\begin{abstract}
The information system is a service at Universitas Muria Kudus. Students and lecturers use several service facilities with various web addresses, such as academic portals, sunan, email, kkn, kawe. The problem is that students must know all the addresses of information systems that exist in MSEs. This is an obstacle, when students / lecturers must access at a different address. To improve services for students and lecturers to create a prototype where on the page accommodate the needs of information system services. The student and lecturer portal prototype functions as a gateway to the information system available at UMK. At the end of this study can facilitate the needs of students and lecturers in the UMK environment to make it easier to access all the systems in MSEs. The research use Waterfall method. In the planning stage of material collection, a system is needed for the academic community.
\end{abstract}

Keywords: portal, web, information system, waterfall.

\section{Introduction}

The development of Internet of Things now requires us to follow it. No longer a rare thing, all activities are required for web-based [1]. It is also applied to Muria Kudus University, all information can be accessed online by lecturers and students.

Information system [2] services and facilities become one of the benchmarks in the assessment of accreditation. UPT PSI is one of the technical implementing units that facilitates the information system needs at Muria Kudus University. So far, information systems that become academic services in universities are still separate access, such as academic information systems, academic portals, SUNAN, compulsory skills applications, KKN, email and so forth. These applications can be accessed on different pages, so students and lecturers must memorize all the addresses of each application.

Access for each application varies, student academic portal and faculty can be accessed on page http://portal.umk.ac.id. SUNAN (sinau temenanan) managed by the educational institution is accessed at http://sunan.umk.ac.id. while the mandatory skill portal and KKN, students access the different address again that is http://portalkawe.umk.ac.id and http://portalkkn.umk.ac.id.

In order to improve the service of existing information system at Muria Kudus University, a student and lecturer portal prototype will be built. The student and lecturer portal prototype was built to accommodate the academic community in using the existing information system facilities at Muria Kudus University more easily and centrally. In application this application provides facilities all information systems used by students and lecturers in one (1) the same ICCSET 2018, October 25-26, Kudus, Indonesia

Copyright (C) 2018 EAI

DOI 10.4108/eai.24-10-2018.2280587 
address. It is expected that students / lecturers do not have to memorize the existing information system at UMK. Only by using the results of this study, students / lecturers can use the integrated information system into a facility of students / lecturers. This portal prototype can run on all platforms, such as on android. Because on this android platform can facilitate all kinds of browsers and also in learning [3][4].

The related research in this research, among others, the first research taken from the development of e-da'wah of the holy mosque web-based holy. In this study contains the need for a container for all activities and history of the Great Mosque Holy. In addition, this container is a place for hospitality for the youth of the mosque in the city of Kudus. E-da'wah is a way takmir teenagers to spread the knowledge of Islam in the city of Kudus and surrounding areas. In addition, E-Da'wah is a media campaign for the city of Kudus, because as it is known the city of Kudus is one of the cities that have two (2) guardians / sunan. The benefit of E-da'wah is not for the Holy Mosque alone, but for other mosques in the city of Kudus [5].

In the second research is taken from digital design library web-based, where the journal discusses about E-book. One effective way of learning is to package the book into digital. Because the E-book model can be read either through mobile phones, tablets, or laptops. Digital library research was conducted at the Faculty of Engineering Muria Kudus University. The purpose of this study is to provide facilities to students and lecturers in research and lectures. The digitalization of this book only in the field of engineering science, whether it is mechanical engineering, electro, industrial and informatics. With the development of gadgets of varying sizes, the digital library is packed in a responsive concept. This is so that the user is comfortable with the look in accordance with the gadgets they use [6].

Research related to the employee portal also submitted Novia on its report entitled the design of the employee portal. Where the report answered the existing problems in Polytechnic Indramayu. This employee portal is created to facilitate users in distributing distributed information to be faster, efficient and accurate. Also expected to improve the quality of service in the field of information delivery for employees to be better [7].

\section{Problem Formulation Problem}

Formulation in research prototype student portal and lecturers of UPT PSI Muria Kudus University web-based is how to build prototype of student portal and lecturer to fulfill requirement of information system at UPT PSI in particular and Muria Kudus University in general. How students / lecturers can use information systems in a container that facilitates all information systems into facilities of students and lecturers at UMK, so no longer memorize one by one link / address of each system. Purpose of research in research of student portal portal and lecturers of UPT PSI Muria Kudus University is web-based that simplify academic community in using information system facility in Muria Kudus University and produce a student and lecturer portal prototype with integrated appearance and function. 


\section{Research Methods}

\subsection{Framework of Thinking}

Figure 1 illustrates the frame of mind in this study. The initial stages of preparation, followed by field observation, system analysis, system design and research results.

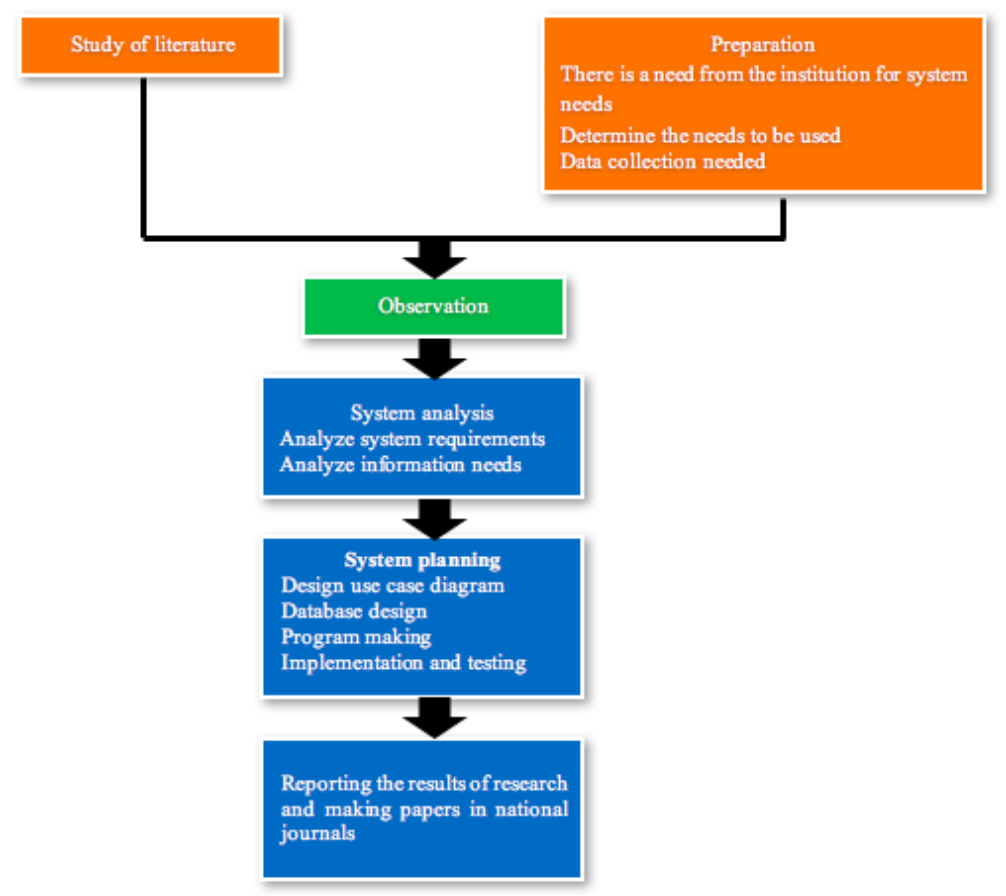

Fig. 1. Framework thought research.

\subsection{Research Methods The}

Method used in the design stage Students and lecturers Portal using Software Engineering Waterfall model. Where software engineering is a technically connected systematic discovery, production and maintenance of high-quality software systems, delivered at the right time and at a high price [8].

The design on the application portal students and lecturers UPT PSI Muria Kudus University web-based use case use model. In Figure 2 there is 1 actor named Admin and use case in it. Admin can access 4 use case by fulfilling use case login first. In use case manage link, admin can manage all link become facility of student. Among other academic portals of students, ports kkn, portal kawe, scholarships, sunan (e learning UMK), simbelmawa (link from kemenristekdikti). In managing icons, the data entered is supporting data from managing 
links. While managing news is news that will be displayed in the initial view. The last one is managing email, here admin can manage email suggestion from user (student).

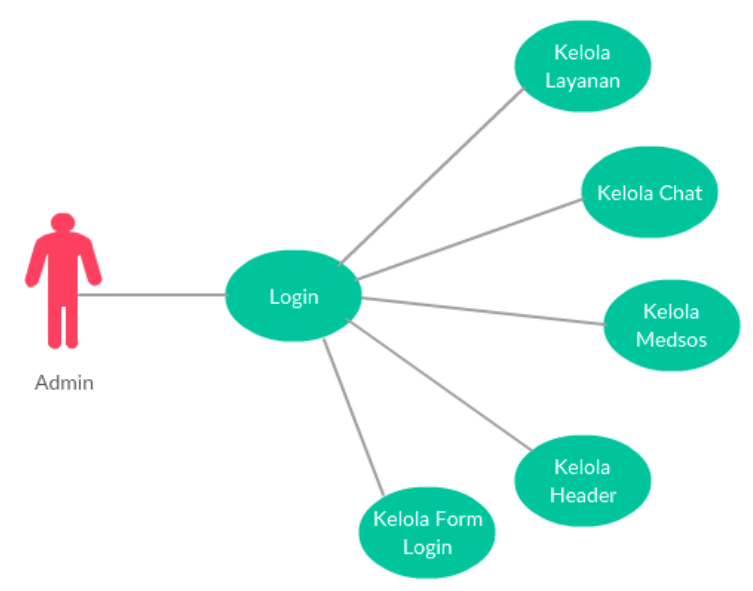

Fig. 2. Use case Admin

In designing Figure 3 describes the use case students as users. Here the student actor does not need to login to use this application. The facility that students get is, can access all links without memorizing their respective link address. In addition there are news updates. Use case on this student contains access links, icons, news and provide advice via email to the related.

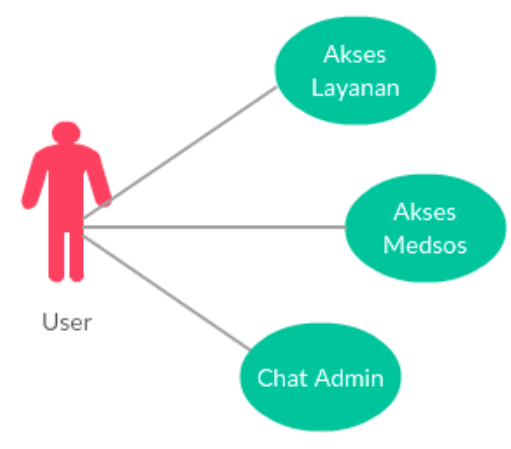

Fig. 3. Use Case Student.

In the process of making the program is a process in which the results of the design that has been adapted to the results of observations described in the form of the program (prototypes portal students and lecturers). In this step is described in the output input design which will be applied to web programming. The first step we prepare the layout for the gate website, this can be seen in Figure 4. 


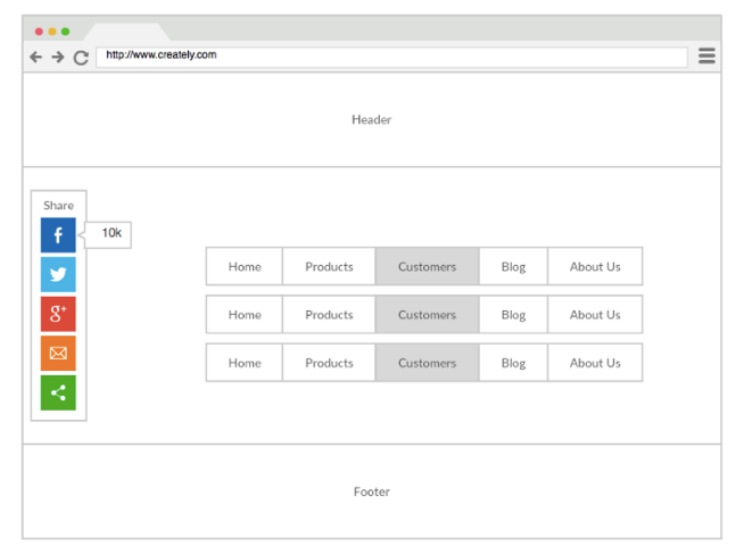

Fig. 4. Web Design Gate.

When the program has been completed then this step is the next process where the implementation process is a process undertaken to implement the program on the server that will the server is on the PSI UPT. As for the testing process is done to know the process is running or not if from every flow of the application.

\section{$4 \quad$ Research Results}

This study produced a website that can be accessed by the entire academic community of Muria Kudus University. This app is under the supervision of the UMK PSC UPT. This web can be used through the page http://gapura.umk.ac.id.

Gapura UMK is one of the services provided by UMK campus for students in order to facilitate access to information system facilities. In Figure 5 shows the main page that can be accessed by students or UMK lecturers. On the main page contains a brief description of the Muria Kudus University Gate. In addition, Muria Kudus University's information system services, as well as information sources for the services.

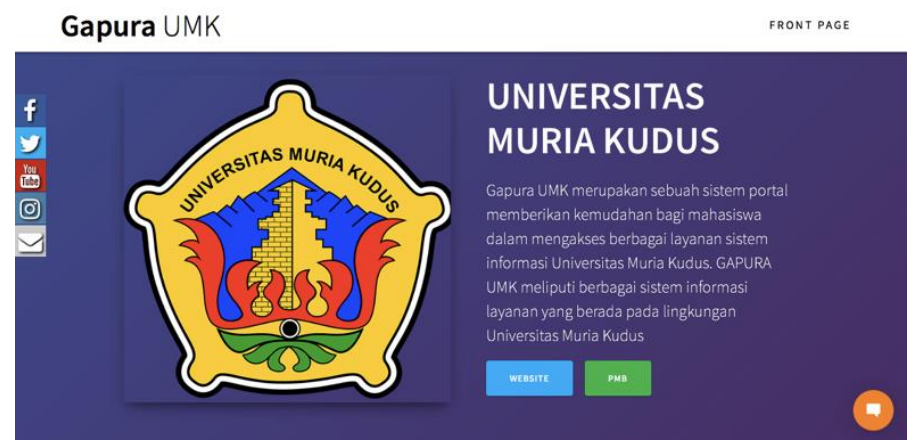

Fig. 5. The main view of Gapura UMK. 
Information system services include academic portal, sunan, KKN, kawe, mail, alumni, digilib, e print, journals, simbelmawa, scholarships. The service is illustrated in Figure 6. With this UMK gate, students no longer have forgotten links or other problems.

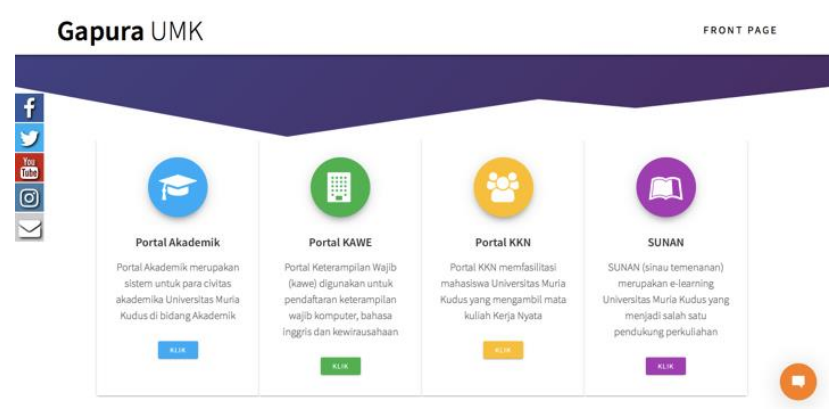

Fig. 6. UMK Information System Services.

The gate of Muria Kudus University also has a page dashboard for management. To enter the dashboard, admins must login first using the username and password that has been provided. Page Login seen in Figure 7.

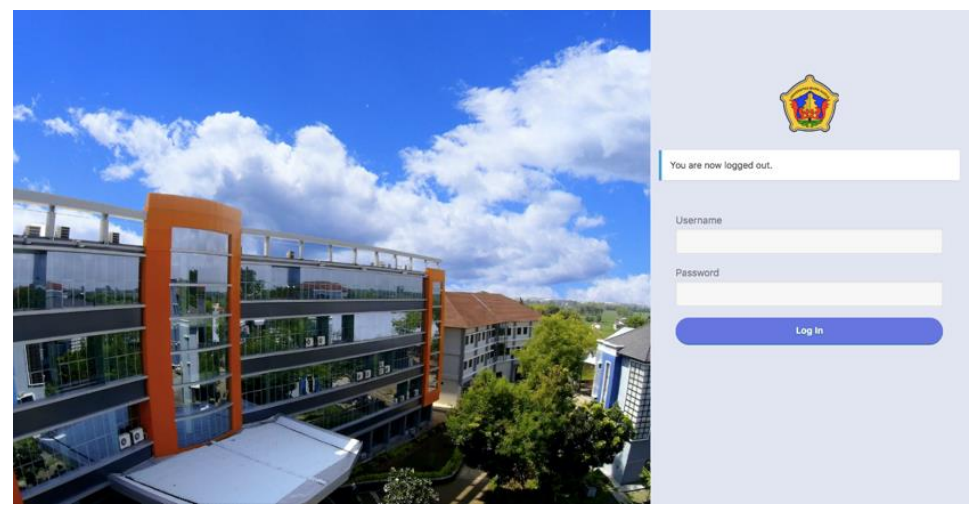

Fig. 7. Login page admin dashboard.

\section{Conclusion}

From the discussion of research that has been described, the researchers can draw some conclusions, among others, prototype portal students and lecturers UPT PSI Muria Kudus University web-based make effectiveness in accessing facilities can be used by students through page http://gapura.umk.ac.id. This prototype is equipped with a helpdesk that students can use if they have trouble or have questions through the facility chat. This gate is a compilation of all information system services that can be accessed by the academic community. 


\section{Acknowledgment}

Thanks to LPPM Muria Kudus University which has facilitated the budget of this research. Thank you also to the UPT PSI Muria Kudus University who helped in this research.

\section{References}

[1] T. Listyorini and R. Rahim, "A prototype fire detection implemented using the Internet of Things and fuzzy logic,” World Trans. Eng. Technol. Educ., vol. 16, no. 1, pp. 42-26, 2018.

[2] A. Mulyanto, Sistem Informasi Konsep dan Aplikasi, 1st ed. Yogyakarta: Pustaka Pelajar, 2009.

[3] E. Kartikadarma, T. Listyorini, and R. Rahim, "An Android mobile RC4 simulation for education,” World Trans. Eng. Technol. Educ., vol. 16, no. 1, pp. 75-79, Apr. 2018.

[4] T. Listyorini and S. Muzid, "Population resizing on fitness improvement genetic algorithm to optimize promotion visit route based on android and google maps API," 2017, p. 060001.

[5] R. Meimaharani, T. Listyorini, and S. Muzid, "E-Dakwah Masjid Agung Kudus Berbasis Web," in Prosiding Seminar Nasional Teknologi dan Informatika, Universitas Muria Kudus, 2016, vol. 1, pp. 283-288.

[6] T. Listyorini and M. Iqbal, "PERANCANGAN PENGEMBANGAN DIGITAL LIBRARY BERBASIS WEB RESPONSIVE," Simetris J. Tek. Mesin Elektro Dan Ilmu Komput., vol. 6, no. 1, p. 69, Apr. 2015.

[7] N. Munafi'ah, Rancang bangun portal pegawai untuk internal politeknik indramayu menggunakan php dajquery dengan mysql sebagai database. Indramayu: Politeknik Indramayu., 2014.

[8] A. B. B. Ladjamudin, Rekayasa Perangkat Lunak, 1st ed. Yogyakarta: Graha Ilmu Yogyakarta, 2006. 